\title{
Reproductive Tourism in Argentina: Clinic Accreditation and its Implications for Consumers, Health Professionals and Policy Makers
}

This is a preprint of an article published in Developing World Bioethics, 2010, 10(2): 59-69 (Published Online First: June 8 2009).

URL: http://www3.interscience.wiley.com/journal/122443658/abstract

Elise Smith, Jason Behrmann, Carolina Martin, Bryn Williams-Jones

\author{
Address for correspondence \\ Bryn Williams-Jones \\ Programme de bioéthique, Département de medecine sociale et préventive \\ Université de Montréal \\ C.P. 6128 , succursale Centre-ville \\ Montréal, Québec, Canada H3C 3J7 \\ bryn.williams-jones@umontreal.ca
}

\section{ACKNOWLEDGEMENTS}

We thank Chris MacDonald and Catherine Olivier for their helpful comments on this manuscript, and acknowledge the generous support of colleagues in Argentina (Ricardo Cesar Andreu, Maria Susana Tabieres and Graciela Maria de Ortuzar). Elise Smith was supported by a COPSE studentship from the Faculty of Medicine (Université de Montréal), Carolina Martin by a Bioethics scholarship from the Faculty of Graduate Studies (Université de Montréal), and Jason Behrmann by scholarships from the Fonds de la recherche en santé du Québec (FRSQ), the Université de Montréal and the APOGEE-Net Network of Canada. This project, part of larger program of research, was supported by grants to Bryn Williams-Jones from the Faculty of Medicine of the Université de Montréal (start-up grant, 2006), the Social Sciences and Humanities Research Council of Canada (SSHRC Institutional pilot grant, 2007), and the International Institute of Research in Ethics and Biomedicine (IIREB travel award to visit Argentina, 2008). 


\begin{abstract}
(224 words)
A subcategory of medical tourism, reproductive tourism has been the subject of much public and policy debate in recent years. Specific concerns include the exploitation of individuals and communities, access to needed health care services, fair allocation of limited resources, and the quality and safety of services provided by private clinics. To date, the focus of attention has been on the thriving medical and reproductive tourism sectors in Asia and Eastern Europe; there has been much less consideration given to more recent 'players' in Latin America, notably fertility clinics in Chile, Brazil, Mexico and Argentina. In this paper, we explore the case of private Argentinean fertility clinics that market reproductive services via the Internet, to examine the context-specific ethical and policy implications. Whether or not one agrees that reproductive services should be made available as consumer goods, the fact is that they are provided as such by private clinics around the world. We argue that basic national regulatory mechanisms are required in countries such as Argentina that are marketing fertility services to local and international publics. Specifically, regular oversight of all fertility clinics is essential to ensure that consumer information is accurate and that marketed services are safe and effective. It is in the best interests of consumers, health professionals and policy makers that the reproductive tourism industry adopt safe and responsible medical practices.
\end{abstract}

Keywords: reproductive technologies, fertility, medical tourism, Argentina, private clinics, regulation

Text: 6085 words

\title{
BACKGROUND
}

'Health' or 'medical' tourism are terms used to describe the travel of consumers from one jurisdiction to another to purchase health care services. ${ }^{1}$ For example, Canadians are visiting the United States to access services not covered by their public health care system; Americans are going to Mexico to obtain alternative therapies or cheaper medications; and the British are visiting India to avoid lengthy waits for heart or knee surgeries. Such forms of medical tourism are not new, but what is new is the significant increase in the number of countries involved in medical tourism and the level of activity relating to this business.

In recent years, the practice of medical tourism has been the subject of significant public debate, as well as academic and policy analyses. ${ }^{2}$ Much publicized cases of medical negligence (and subsequent malpractice lawsuits) - due in part to the wide variation in or even absence of regulation and legal frameworks - have attracted attention and raised concerns for consumers and health professionals. ${ }^{3}$ Discrepancies in how countries regulate and compensate patients affected by medical malpractice are particularly worrisome. For example, legislative frameworks in India allow for the provision of very modest compensation to patients, when compared with

\footnotetext{
${ }^{1} \mathrm{H}$. Widdows. Is Global Ethics Moral Neo-Colonialism? An Investigation of the Issue in the Context of Bioethics. Bioethics 2007; 21: 305-315

${ }^{2}$ R. Marcelo. 2003. India Fosters Growing 'Medical Tourism' Sector. The Financial Times 2 Jul. Available at: http://yaleglobal.yale.edu/display.article?id=2016 [Accessed 8 Oct 2008]; J. Cherian. 2006.

Accreditation of Hospitals to Promote Top Medical Tourism Destination in India. All Headline News 27 July. Available at: http://www.allheadlinenews.com/articles/7004351049 ; J. Frenk \& O. Gomez-Dantes. Globalization and the Challenges to Health Systems. Health Aff 2002; 21: 160-165.

${ }^{3}$ G. Semenza. 2007. The Medical Tourist: U.S. Doctors Warn About the Dangers of Cheap Surgeries in Foreign Countries. Victoria Advocate June 17
} 
much more generous provisions available in most Western countries. ${ }^{4}$ The average medical tourist is also likely ill informed as to the specifics of malpractice laws in foreign countries, and it is doubtful whether they would even have legal recourse in the event of negligent treatment. ${ }^{5}$ Such legal information is often not readily available to consumers (e.g. not posted on medical tourism websites, possibly in an unfamiliar language), and they might thus reasonably, if incorrectly, assume that they are protected by similar legal mechanisms as in their home countries.

Opponents of medical tourism assert that it benefits only the wealthy and allows people to 'jump the queue' to unfairly receive services that less affluent individuals, either in the host country or in foreign jurisdictions, cannot afford to purchase. The underlying principle is that access to needed health care is a basic human right or a fundamental good and should not be managed or provided as a free market commodity like any other. ${ }^{6}$ Critics point out that medical tourism undermines this public good; free market dynamics create economic vulnerability for poorer countries who must use their health care systems to generate wealth by targeting foreign consumer demand for technology-intensive tertiary care, instead of providing essential primary health care for their citizens. ${ }^{7}$

Those who advocate in favour of medical tourism assert that there is little need to worry about autonomous consumers who have the financial means to seek out health care in foreign nations; as wealthy individuals, they have the power to 'shop around' and evaluate the risks and benefits of various services, and so should be able to freely purchase those services and products they desire. Also, the point is made that the health care industry is economically important in both developed and developing countries and thus ought to be encouraged for the economic benefit of all citizens. ${ }^{8}$

\section{Reproductive Tourism in Latin America}

Although there are many categories of medical tourism, we will limit our analysis to the provision of fertility services, or reproductive tourism, a subcategory of medical tourism that is receiving increased attention. ${ }^{9}$ For the most part, reproductive tourism has been directed at wealthy North American or European couples who travel to other developed countries to access assisted reproductive technologies (ART) such as in-vitro fertilization (IVF) or pre-implantation genetic diagnosis (PGD). The main interest for these individuals to become medical tourists is the high cost, the long waiting lists, or even the absence of ART services at home; ${ }^{10}$ prominent examples include UK couples visiting the US to obtain PGD and IVF to conceive so-called 'saviour sibling' children (a child who will be an immuno-compatible match and supply a life-saving tissue commonly umbilical stem cells - to a gravely ill sibling). ${ }^{11}$

\footnotetext{
${ }^{4}$ R. Bhat. Regulating the Private Health Care Sector: The Case of the Indian Consumer Protection Act. Health Policy Plan 1996; 11: 265-279

${ }^{5}$ P. Mirrer-Singer. Medical Malpractice Overseas: The Legal Uncertainty Surrounding Medical Tourism. Law Contemp Probl 2007; 70: 211-232

${ }^{6}$ N. Daniels. Justice, Health, and Health Care. Am J Bioeth 2001; 1: 2-16

${ }^{7}$ A.B. Ramirez de Arellano. Patients without Borders: The Emergence of Medical Tourism. Int $J$ Health Serv 2007; 37: 193-198

${ }^{8}$ B. Starfield. Improving Equity in Health: A Research Agenda. Int J Health Serv 2001; 31: 545-566

${ }^{9}$ G. Pennings. Reproductive Tourism as Moral Pluralism in Motion Br Med J 2002; 28: 337-341

${ }^{10}$ E. Blyth \& A. Farrand. Reproductive Tourism - a Price Worth Paying for Reproductive Autonomy? Critical Social Policy 2005; 25: 91-114

${ }^{11}$ M. Spriggs \& J. Savulescu. "Saviour Siblings". J Med Ethics 2002; 28: 289
} 
In the last 10 years, private fertility clinics have appeared in developing countries, offering a wide variety of fertility services at much lower prices than clinics in developed countries. ${ }^{12}$ While the 'big players' in medical tourism, such as India and Poland, are actively involved in the fertility sector, so too now are Latin American countries such as Brazil, Chile, Mexico and Argentina. As with their North American, European and Asian counterparts, private fertility clinics in Latin America are using the Internet to reach potential consumers in the lucrative global market for assisted reproductive services. Next to Brazil and Mexico, Argentina is the Latin American country with the most well-established private fertility industry. It is the latest 'new player' in the medical tourism industry and it has become a highly sought after and affordable destination for medical tourists, particularly following the strong devaluation of the peso in 2002, which had previously been at parity with the American dollar. ${ }^{13}$

Most fertility clinics in Argentina are private entities as there are very few public providers; access to some fertility services is covered by public or private health insurance plans, but for the most part these services necessitate direct out-of-pocket payment by patients. Many of these private fertility clinics appear to operate on a cost-recovery basis instead of a profitseeking business model. Nonetheless, as we will show, discrepancies between Argentinean fertility clinics, in terms of their service provision and marketing tactics, reveal an emerging divide between those clinics offering health services to local patients, and those concentrating on the provision of services for foreign clients. This divide or targeted specialization of clientele raises several ethical concerns. In particular, we identify questionable marketing and business practices on the part of clinics that cater to medical tourists. These practices raise concerns about adequate informed consent, marketing of health products as consumer goods, and corporate and professional responsibility.

In absence of international moral consensus about the acceptability of reproductive tourism, this sector of the medical tourism industry (as well as the industry more generally) has remained poorly regulated. Whether one is an opponent or an advocate of reproductive tourism, the fact is that it is already a common practice and stopping it would seem unrealistic. This reality in no way undermines the need for policies and guidelines to ensure the safe and effective provision of medical services. However, as is well illustrated by the enormous variation in judicial and policy responses to developments in stem cell research, there will be very important regional differences in policy and public debate that will turn on religious, cultural, political, institutional and historical factors. ${ }^{14}$ No single country can simply copy the policy and regulatory mechanism of another to deal with the local challenges posed by biotechnology innovations. Reproductive tourism is no exception.

In this paper, we aim to participate in the ethics and policy debate about the regulation of reproductive tourism. To do so, we begin by presenting the results of a comparative website analysis of Argentinean fertility clinics, so as to: 1) better understand the diversity of this private sector; 2) distinguish specific differences in service provision; and 3) reflect on the implications for health care consumers, professionals and policy makers. We conclude by suggesting some general guidelines for improving regulation in Argentina. In particular, we highlight the need to consider the specific cultural and moral entities of a country in the process of developing

\footnotetext{
${ }^{12}$ K. Evans \& A.E.S. Samson. 2004. Facing the Challenges of New Reproductive Technologies. Young Women and Leadership. 8. Available at: http://www.iwtc.org/ideas/4_facing.pdf [Accessed 8 Oct 2008].

${ }^{13}$ MedRetreat. 2008. Argentina. Available at: http://www.medretreat.com/destinations/argentina.html [Accessed 8 Oct 2008].

${ }^{14}$ R.M. Isasi \& B.M. Knoppers. Mind the Gap: Policy Approaches to Embryonic Stem Cell and Cloning Research in 50 Countries. Eur J Health Law 2006; 13: 9-26
} 
regulation to mitigate the negative implications associated with the growing reproductive tourism industry.

\section{METHODS \& RESULTS}

Our study, which was conducted in July and August 2007, involved two steps: 1) a detailed search of Latin American registries of fertility clinics, and 2) a general web search, using the Google $®$ and $Y a h o o \circledR$ search engines, for Argentinean fertility clinics.

\section{1) Registries for Latin American fertility clinics}

There are two main registries that have developed guidelines applicable to Argentinean fertility clinics: The Sociedad Argentina de Medicina Reproductiva (SAMeR) and the Registro Latinoamericano de Reproducción Asistida (RLA). SAMeR oversees the operations of clinics, regulates service quality, laboratory procedures and staff qualifications in Argentina. ${ }^{15}$ This oversight is comparable, yet more limited than that of the RLA, which oversees procedures performed in 141 fertility clinics throughout Latin America. We focused our analysis on the data included in the RLA since their registry is more comprehensive than that of SAMeR.

The RLA is maintained by the Latin America Network of Assisted Reproduction (Red Latinoamericana de Reproduccion Asistida, REDLARA). ${ }^{16}$ REDLARA is a scientific and educational body that provides oversight of fertility services through the compilation of an annual catalogue of clinics from across Latin America. These clinics are registered or subclassified as either 'affiliated' or 'accredited'. Accredited clinics are those that have submitted data to REDLARA that indicate an appropriate level of quality control and adherence to procedural guidelines. Parameters include information regarding: controls used to monitor laboratory quality, use of model client informed consent forms, descriptions of laboratory equipment, and descriptions of the clinical installations. ${ }^{17}$ Upon submission of this data, inspectors who are members of REDLARA - typically clinicians or biologists known to have no vested interest in the clinic - inspect the facility to validate the data submitted for accreditation. If discrepancies are identified but deemed not particularly grave, the clinic will be classified as 'affiliated'; the clinic then has three years to rectify inadequacies to obtain full accreditation. In summary, accreditation implies that a clinic is operating under accepted norms of practice, while affiliated clinics are in the process of reaching this gold standard.

It would seem logical to assume that, in the case of medical tourism, RLA accreditation status might influence a consumer's choice as to which clinic they would prefer to visit for treatment. Although not likely to be widely known by health care consumers (the information on the RLA website is geared towards health professionals), the RLA is a potentially very useful search instrument; its website was easily accessible in our Google searches for information concerning the regulation of fertility clinics. A link to this registry is also provided on the websites of the World Health Organization and the Pan American Health Organization. Table 1 (below) lists the subset of Argentinean fertility clinics included in the RLA, with a summary of the services provided, accreditation status, and website language.

\footnotetext{
${ }^{15}$ SAMeR. Sociedad Argentina De Medicina Reproductiva. Available at: http://www.samer.org.ar/ [Accessed 8 Oct 2008].

${ }^{16}$ REDLARA. Red Latinoamerican de Reproduccion Assistida. Available at: http://www.redlara.com/ [Accessed 8 Oct 2008].

${ }_{17}^{17}$ REDLARA. Accreditation Available at: http://www.redlara.com/ing/REGISTRO.ASP [Accessed 8 Oct 2008].
} 
Table 1: Argentine Fertility Clinics Listed in the RLA

\begin{tabular}{|c|c|c|c|}
\hline Name of Private Institution & $\begin{array}{l}\text { Fertility Services \& Procedures } \\
\text { Offered }\end{array}$ & $\begin{array}{l}\text { Accredited } \\
\text { or Affiliated }\end{array}$ & $\begin{array}{l}\text { Language of } \\
\text { Clinic's } \\
\text { Website }\end{array}$ \\
\hline $\begin{array}{l}\text { AMERIS - Centro de Fertilidad, } \\
\text { Ginecologia y Urologia } \\
\text { www.amerisbb.com.ar }\end{array}$ & Site under construction & Accredited & Spanish \\
\hline $\begin{array}{l}\text { C.I.G.O.R Centro Integral de Ginecologia, } \\
\text { Obstetricia y Reproduccion } \\
\text { www.cigorcentro.com.ar }\end{array}$ & $\begin{array}{l}\text { Ovarian stimulation, IUI, IVF, ICSI, } \\
\text { Oocyte Donation }\end{array}$ & Accredited & $\begin{array}{l}\text { English } \\
\text { Spanish }\end{array}$ \\
\hline $\begin{array}{l}\text { CEFEP - Centro para la Fertilidad de la } \\
\text { Pareja } \\
\text { www.cepef.org.ar }\end{array}$ & Site under construction & Accredited & NA \\
\hline $\begin{array}{l}\text { CER Instituto Médico } \\
\text { www.cermed.com }\end{array}$ & $\begin{array}{l}\text { Simply notes fertility } \\
\text { treatment/services }\end{array}$ & Accredited & English \\
\hline $\begin{array}{l}\text { CERH - Centro de Estudios en } \\
\text { Reproduccion Humana }\end{array}$ & NA & Accredited & Spanish \\
\hline $\begin{array}{l}\text { CIMER - Centro de Invertigaciones en } \\
\text { Medicina Reproductiva } \\
\text { www.cimer.com }\end{array}$ & $\begin{array}{l}\text { IUI, IVF, ICSI, AH, Gametes } \\
\text { donation, cryopreservation of } \\
\text { gametes and embryos, } \\
\text { study and diagnosis of partner, } \\
\text { Ultrasound monitoring of the } \\
\text { ovulation. }\end{array}$ & Affiliated & Spanish \\
\hline $\begin{array}{l}\text { CRECER } \\
\text { www.crecerreproduccion.com.ar }\end{array}$ & $\begin{array}{l}\text { IUI, IVF, ICSI, Cryopreservation of } \\
\text { embryos }\end{array}$ & Affiliated & Spanish \\
\hline $\begin{array}{l}\text { Centro Médico Fertilab } \\
\text { www.fertilab.com.ar }\end{array}$ & $\begin{array}{l}\text { IUI, IVF ICSI, GIFT, ZIFT, } \\
\text { Cryopreservation of embryos }\end{array}$ & Accredited & Spanish \\
\hline $\begin{array}{l}\text { Centro de Estudios en Ginecologia y } \\
\text { Reproduccion (CEGYR) } \\
\text { www.cegyr.com }\end{array}$ & $\begin{array}{l}\text { IUI, IVF, ICSI, Cryopreservation of } \\
\text { gametes and embryos, PGD, AH, } \\
\text { Gametes donation }\end{array}$ & Accredited & $\begin{array}{l}\text { Spanish } \\
\text { English }\end{array}$ \\
\hline $\begin{array}{l}\text { Centro de Reproduccion } \\
\text { www.centrodereproduccion.com }\end{array}$ & IUI, IVF, ICSI & Accredited & $\begin{array}{l}\text { English } \\
\text { Spanish }\end{array}$ \\
\hline $\begin{array}{l}\text { Centro de la Mujer } \\
\text { www.hospitalitaliano.org.ar }\end{array}$ & General notes about services & Accredited & Spanish \\
\hline $\begin{array}{l}\text { Fecundart - Instituto Integral de } \\
\text { Reproduccion Asistida } \\
\text { www.fecundart.com.ar }\end{array}$ & IVF, GIFT, ICSI & Accredited & Spanish \\
\hline $\begin{array}{l}\text { Fecunditas } \\
\text { www.fecunditas.com / www.PGD- } \\
\text { Fecunditas.com }\end{array}$ & $\begin{array}{l}\text { IVF, AH, PGD, Gametes and } \\
\text { Embryos donation, Cryopreservation } \\
\text { of gametes and embryos }\end{array}$ & Accredited & $\begin{array}{l}\text { English } \\
\text { Spanish }\end{array}$ \\
\hline $\begin{array}{l}\text { GENS - Centro Especializado en } \\
\text { tratamientos para la mujer } \\
\text { (web-site not available) }\end{array}$ & NA & Affiliated & NA \\
\hline $\begin{array}{l}\text { Halitus Instituto Médico } \\
\text { www.halitus.com }\end{array}$ & $\begin{array}{l}\text { IVF, ICSI, Oocyte and embryo } \\
\text { donation, PGD }\end{array}$ & Accredited & Spanish \\
\hline $\begin{array}{l}\text { Instituto Prefer } \\
\text { www.iprefer.com.ar }\end{array}$ & $\begin{array}{l}\text { IVF, IUI, GIFT, } \\
\text { Cryopreservation of gametes and } \\
\text { embryos } \\
\text { Oocyte donation, } \mathrm{AH}\end{array}$ & Accredited & $\begin{array}{l}\text { Spanish } \\
\text { (Can answer } \\
\text { questions in } \\
\text { English) }\end{array}$ \\
\hline $\begin{array}{l}\text { Instituto de Medicina Reproductiva } \\
\text { www.institutomedicinareproductiva.com }\end{array}$ & $\begin{array}{l}\text { IVF, ICSI, IUI, Cryopreservation of } \\
\text { gametes }\end{array}$ & Accredited & Spanish \\
\hline $\begin{array}{l}\text { PROAR - Programa de Asistencia } \\
\text { Reproductiva de Rosario } \\
\text { www.proar-rosario.com.ar }\end{array}$ & IVF, IUI, ICSI, GIFT, TET & Accredited & $\begin{array}{l}\text { English } \\
\text { Spanish }\end{array}$ \\
\hline
\end{tabular}




\begin{tabular}{|l|l|l|l|}
\hline $\begin{array}{l}\text { PROCREARTE - Red de Medicina } \\
\text { Reproductiva y Molecular } \\
\text { www.procrearte.com }\end{array}$ & $\begin{array}{l}\text { IVF, IUI, ICSI, GIFT, AH, } \\
\text { Cryopreservation of embryos, PGD, } \\
\text { Oocyte donation }\end{array}$ & Accredited & Spanish \\
\hline $\begin{array}{l}\text { SERESA-Centro de Salud Reproductiva } \\
\text { Salta } \\
\text { www.saresa.com.ar }\end{array}$ & $\begin{array}{l}\text { IUI, IVF, ICSI } \\
\text { Ovarien stimulation }\end{array}$ & Accredited & Spanish \\
\hline $\begin{array}{l}\text { Unidad de Fertilisas San Isidro (UNIFER) } \\
\text { www.unifer.com.ar }\end{array}$ & NA & Accredited & NA \\
\hline
\end{tabular}

Legend: In Vitro Fertilization (IVF); Intra Cytoplasmic Sperm injection (ICSI); Intra-Uterine Insemination (IUI), Assisted Hatching (AH), gamete intrafallopian transfer (GIFT), zygote intrafallopian transfer (ZIFT), Tubal Embryo Transfer (TET), prenatal genetic diagnosis (PGD), Information unavailable at the time of this work (NA).

\section{2) The Web search}

Using the Google and Yahoo search engines, we conducted keyword searches for: 'medical tourism', 'medical trips to Argentina', 'fertility clinics in Argentina', and 'reproduction clinics in Argentina'. The rationale for this approach was to simulate the search methods that a hypothetical 'average health care consumer' might use to shop for medical tourism services. The general web search identified some of the sites found in the RLA, as well as two additional fertility clinics, Plenitas and Go Sculptura (see Table 2).

Table 2: Non-Accredited Private Argentine Fertility Clinics

\begin{tabular}{|c|c|c|c|c|}
\hline $\begin{array}{l}\text { Name of Private } \\
\text { Institution }\end{array}$ & $\begin{array}{l}\text { Fertility Services and } \\
\text { Procedures Offered }\end{array}$ & $\begin{array}{l}\text { Prices } \\
\text { (in \$US) }\end{array}$ & $\begin{array}{l}\text { Services offered to medical } \\
\text { tourists }\end{array}$ & $\begin{array}{l}\text { Language of } \\
\text { Clinic's Website }\end{array}$ \\
\hline $\begin{array}{l}\text { Plenitas } \\
\text { www.plenitas.com }\end{array}$ & $\begin{array}{l}\text { IVF } \\
\text { Oocyte donation } \\
\text { Cryopreservation of } \\
\text { Embryos } \\
\text { ICSI } \\
\text { Cryopreservation of } \\
\text { Sperm }\end{array}$ & $\begin{array}{l}\$ 4,795 \\
\$ 8,405 \\
\$ 2,295 \\
\$ 4,995 \\
\$ 995\end{array}$ & $\begin{array}{l}\text { Including hotel stay, bilingual } \\
\text { assistant, transportation }\end{array}$ & $\begin{array}{l}\text { Spanish } \\
\text { English }\end{array}$ \\
\hline $\begin{array}{l}\text { Go Sculptura } \\
\text { www.gosculptura.com }\end{array}$ & $\begin{array}{l}\text { IVF } \\
\text { Donor eggs \& embryos } \\
\text { ICSI }\end{array}$ & $\begin{array}{l}\$ 5,192 \\
\$ 8,995 \\
\$ 5,395\end{array}$ & $\begin{array}{l}\text { Including hotel stay, personal } \\
\text { assistant, relaxation } \\
\text { packages }\end{array}$ & $\begin{array}{l}\text { Spanish } \\
\text { English }\end{array}$ \\
\hline
\end{tabular}

Legend: In Vitro Fertilization (IVF); Intra Cytoplasmic Sperm injection (ICSI).

These two clinics are noteworthy because they do not appear in the registries (RLA or SAMeR), and thus raised questions concerning the degree of regulatory oversight of these clinics. Subsequent comparisons between the clinics listed in Tables 1 and 2 identified several particularities, which will be discussed in further detail below. Other non-Argentinean fertility clinics (e.g. in Brazil, Chile, and Mexico) that appeared in these search results were excluded from our analysis.

\section{Comparing accredited and non-accredited clinics}

The range of services offered by the accredited (and affiliated) and non-accredited clinics varies significantly. Accredited institutions typically offer a more extensive list of fertility procedures while the non-accredited clinics focus on more generic fertility procedures such as IVF and intracytoplasmic sperm injection (ICSI). The more complicated procedures that require invasive protocols such as intrauterine insemination (IUI) and gamete intrafallopian transfer (GIFT), are provided exclusively by accredited clinics. This is consistent with observations previously made 
in the ethics and public policy literatures relating to the privatization of health care service provision; that is, profit-seeking institutions prefer to focus on the 'low hanging fruit' or the relatively uncomplicated therapies that can produce a high profit margin. ${ }^{18}$ Although all the accredited and non-accredited clinics are private entities, those clinics participating in the registries (SAMeR or RLA) and thus accepting some form of oversight appear to have adopted a less explicitly profit-seeking model of operation.

Interestingly, many of the non-accredited Latin American fertility clinics that we found through our web search also operate within larger private medical institutions that provide a variety of other lucrative procedures, most notably cosmetic surgery. By contrast, accredited (or affiliated) fertility clinics specialise exclusively in fertility treatments; they do not provide non-fertility related services. There is also an important difference in the content and accessibility of websites of accredited and non-accredited clinics. In addition to having their own individual websites, both of the non-accredited clinics in our study - Plenitas and Go Sculptura - market themselves more widely on the Internet through links on general sites dedicated to medical or reproductive tourism, blogs and on-line forums. By contrast, the websites of the accredited clinics are almost exclusively linked to from the registries, and not from other commercial health care websites. Lastly, the non-accredited clinics typically highlight in their packages the availability of complementary tourist services, such as hotel accommodations or the aid of bilingual assistants; accredited clinics focus solely on describing the fertility services they offer.

To summarise, we observed an emergence of two subcategories of private fertility practices in Argentina: 1) accredited and affiliated clinics - part of the general healthcare industry providing a broad array of fertility services to both local and foreign populations, and 2) nonaccredited clinics specialised in providing a limited range of lucrative fertility services as part of medical tourism packages.

\section{DISCUSSION}

The private provision of fertility services raises numerous important ethical issues that merit further consideration, but for the purposes of this paper we will focus on those issues arising from a lack of regulatory oversight of non-accredited clinics. That is, we examine the implications of fixed or package pricing, the explicit targeting of Western consumers, and the selective disclosure of information for important medical procedures.

Unlike the rather minimalist and often simple websites employed by most accredited clinics, the non-accredited clinics deploy very sophisticated and easy to navigate websites with appealing messages and presentation. Similar to the 'all inclusive' vacation packages offered by tourist resorts and travel agencies, Plenitas and Go Sculptura offer 'all inclusive, full package' deals. These include hotel accommodation, local transportation, and a personal bilingual assistant - as well as the fertility treatment - in one fixed price; this marketing tactic is also used by medical brokerage companies that offer services to facilitate the medical tourism experience. ${ }^{19}$ The appeal of such packages is obvious: health care consumers need not worry about any of the practical details of their trip (e.g. budgeting, travel arrangements, language barriers), and can instead focus on obtaining the quality medical services that they desire, combined with a vacation. Further, the non-accredited clinics in Argentina offer much more competitive prices for services in comparison with clinics in North America or Europe; for example, IVF in the US runs

\footnotetext{
${ }^{18}$ M. Gold. Can Managed Care and Competition Control Medicare Costs? Health Aff 2003; Jan-Jun: W3176-188. Available at: http://content.healthaffairs.org/cgi/reprint/hlthaff.w3.176v1 [Accessed 8 Oct 2008].

${ }^{19}$ L. Turner. First World Health Care at Third World Prices': Globalization, Bioethics and Medical Tourism. Biosocieties 2007; 2: 303-325
} 
upwards of US $\$ 10,000$ per cycle of treatment (without any tourist-friendly add-ons), approximately double the price offered by Plenitas or Go Sculptura.

However, fixed pricing can be contentious because it transforms complex and individually specific medical procedures into a 'one-size-fits-all' package. Economic studies conducted in the US have shown that there are a number of factors associated with specific and distinct physical attributes of a patient which would inevitably necessitate cost variations for a given ART procedure. ${ }^{20}$ So while fixed pricing may be an effective marketing tactic, it may not provide the flexibility required to adequately reflect cost increases incurred as a result of specific individual patient requirements. The clinic would thus have to factor into their standard package some margin to absorb unforeseen cost variations; while this might well be feasible, it also raises concerns about incentives to 'cut corners' in the quality of service if a patient treatment program becomes more complicated, and thus more expensive, than anticipated. We could not determine the true costs of fertility services in Argentina because accredited clinics (a reasonable standard for comparison pricing) provided no information online about the underlying cost elements or structure of their prices for a given fertility treatment, nor did nonaccredited clinics provide a break down of the exact costs that made up their fixed-price packages.

To entice prospective clients, non-accredited clinics also use economic arguments, language and analogies that would be particularly familiar to Western audiences. For example, the Plenitas website mentions that there is 'no catch' and that the low prices offered are the result of advantageous exchange rates between the Argentine peso and the US dollar. In a clever comparison, the Plenitas website explains that a Big Mac bought in the US costs \$3, while one purchased in Argentina would be only $\$ 1.6$, thus highlighting the important price advantage for consumers accessing services in Argentina. 'The Big Mac is exactly the same, but the price is related to the economy of the country where it is sold. ${ }^{21}$ Yet such simple language, while a very effective means of describing the price difference, is not unproblematic.

It is certainly the case that popular culture references (e.g. to the Big Mac) can help consumers better understand the reason for price differences. But such language can also contribute to the erroneous perception that specialized health services, such as ARTs, are not all that different from other consumer goods, such as tourist attractions and luxury hotel accommodations. Without entering into the larger debate about the ethics of public or private provision and/or purchase of health care services, it is still possible to make a convincing case that access to health care products and services - such as prescription medicines, surgeries, or ARTs require special consideration because of the very great potential health risks involved (e.g. adverse drug reactions, hospital born infections) and the need for guidance and support by accredited medical professionals. In the case of fertility services, important risks include the birth of multiple low-weight babies and a higher incidence of fetal developmental abnormalities.

We are not arguing that the commercial nature of private health care delivery necessarily entails an unjustified commodification of such services. Rather, it is our contention that the marketing of fertility services as part of reproductive tourism packages - as done by the non-accredited clinics examined in our study - camouflages or trivializes the importance of the risks involved. Indeed, prospective clients may well underestimate or overlook important considerations related

\footnotetext{
${ }^{20}$ M.E. McClure. 1996. The "ART" Of Medically Assisted Reproduction: An Embryo Is an Embryo Is an Embryo. In Birth to Death: Science and Bioethics. D.C. Thomasma and T.K. Kushner, eds. Cambridge: Cambridge University Press.

${ }^{21}$ Plenitas. Plenitas. Available at: http://www.plenitas.com [Accessed 8 Oct 2008].
} 
to quality of care, safety, and the regulation of health care services, factors that are critical to their own health. ${ }^{22}$ The notion of caveat emptor, or 'buyer beware', is insufficient protection in the case of reproductive or medical tourism.

Another concern in the presentation or marketing of fertility services by the non-accredited clinics is related to their use of competitor rankings. For example, Plenitas differentiates itself and Argentina more generally - as being a more favourable option for potential clients, in comparison with competitors in India, Poland, Colombia and Thailand. Using tables presenting comparative data on national populations, economy, social development, and health, the Plenitas website ${ }^{23}$ makes the case that Argentina has one of the highest literacy rates, GDP, industrial production growth rate, and most physicians per population. The clear implication is that Argentina is the most sophisticated or Western-like country, and thus consumers should not be concerned about quality or safety issues. However, it should be noted that Plenitas has advantageously selected competitors in poorer nations while carefully ignoring other popular and affordable destinations such as Mexico or Brazil, neighbouring countries that present stiffer competition in the medical tourism industry. ${ }^{24}$

One can obviously make a clear distinction between legitimate positive corporate selfpromotion, and the presentation of misleading or false advertising, especially in comparison with competitors; the former is ethically and legally acceptable, the latter is not and is likely to provide the grounds for lawsuits. But the distinction becomes much harder to make when the promotion involves the presentation of selective or even slightly biased information. And, when there is limited access to impartial information sources about service providers - as is the case for the non-accredited clinics - consumers will be far less able to make informed decisions about the purchase of sophisticated and complex medical services. ${ }^{25}$

A final point to consider is the relative ease of access in locating the websites of non-accredited clinics, in comparison to accredited (or affiliated) clinics. The former are quickly found with a simple Internet search (such as with Google), whereas the latter take much more effort and time to find. To expand, accredited clinics are found indirectly through registry websites and the information is usually available only in Spanish. (The REDLARA site is linked to from other fertility sites, but this is not evident when a direct Internet search is conducted.) Nor is it obvious from the information on the non-accredited websites that there are differences in accreditation (or what this entails) and regulation of fertility clinics. Thus it is reasonable to ask whether potential health care consumers have the capacity to differentiate between accredited or nonaccredited clinics, or even realise that the former are regulated by oversight bodies while the latter are not.

\section{Regulation, safety and consumer satisfaction}

It is not possible for democratic societies, whether they are in developed or developing countries, to protect their populations by regulating or controlling the quality or veracity of

\footnotetext{
${ }^{22}$ Turner. op cit. note 19.

${ }^{23}$ Plenitas. op cit. note 21.

24 J. Davidow. 2006. Cost-Saving Surgery Lures 'Medical Tourists' Abroad. Seattle Post-Intelligencer's 24 Jul. Available at: http://seattlepi.nwsource.com/health/278630_medtour24.html [Accessed 9 Oct 2008].

$25 \mathrm{~J}$. Huh \& B.J. Cude. Is the Information "Fair and Balanced" in Direct-to-Consumer Prescription Drug Websites? Journal of Health Communication 2004; 9: 529-540; S.E. Gollust, S.C. Hull \& B.S. Wilfond. Direct-to-Consumer Sales of Genetic Services on the Internet. Genetics in Medicine 2003; 5: 332-337
} 
information presented by foreign companies on the Internet. ${ }^{26}$ However, it is possible for host countries to set standards by regulating the practices (e.g. in terms of marketing or laboratory quality) of local clinics, through general regulations on corporate advertising and focused national policies or registries (such as REDLARA or SAMeR) ${ }^{27}$ Most countries with advanced health care systems such as Canada, France, or the United Kingdom have policies and regulations to control the development, commercialization and use of health care services; reproductive technologies are no exception. In fact, the contentious nature of many ART procedures requires that they be subject to specific, and sometimes very restrictive, legislation and regulation. ${ }^{28}$

In Latin America, Brazil and Mexico have some form of government regulation governing ART; ${ }^{29}$ Argentina, lacking such regulation, relies on professional guidelines and national or regional registries. ${ }^{30}$ SAMeR and REDLARA, which as previously mentioned, oversee the operations of accredited and affiliated clinics (Table 1), regulate service quality, laboratory procedures and staff qualifications; notably, this does not include evaluation of marketing practices. ${ }^{31}$ According to the REDLARA website, $90 \%$ of fertility clinics in Latin America are registered and therefore regulated. ${ }^{32}$ The remaining $10 \%$, such as the non-accredited clinics presented in this article, are not regulated by any external institution or oversight body. The only remaining possible regulation of these clinics would be through professional codes of ethics or internal institutional practice guidelines.

Since there is no formal legislation in Argentina to empower oversight bodies to regulate all fertility clinics, the quality of procedures may vary widely. ${ }^{33}$ Oversight of health, safety or professional credentials is limited to the aforementioned national and regional registries, but accreditation through these registries is voluntary. There is no control over non-accredited fertility clinics such as Plenitas and Go Sculptura which chose not to be associated with the registries. The result is that non-accredited clinics have total discretion over how to run their clinics and which services to offer, and they are free from official oversight. ${ }^{34}$

\footnotetext{
${ }^{26}$ B. Williams-Jones. Where There's a Web, There's a Way: Commercial Genetic Testing and the Internet. Community Genet 2003; 6: 46-57; Gollust, Hull \& Wilfond. op cit. note 25.

${ }^{27}$ Human Genetics Commission. 2003. Genes Direct: Ensuring the Effective Oversight of Genetic Tests Supplied Directly to the Public. London: Human Genetics Commission, Department of Health. Available at: http://www.hgc.gov.uk/UploadDocs/DocPub/Document/genesdirect_full.pdf [Accessed 9 Oct 2008].

${ }^{28}$ House of Commons Science and Technology Committee (UK). 2005. Human Reproductive Technologies and the Law. London. Available at:

http://www.publications.parliament.uk/pa/cm200405/cmselect/cmsctech/7/702.htm [Accessed 8 Oct 2008].

${ }^{29}$ In Brazil, ARTs are governed by a resolution from the federal medical council; in Mexico the subject of ARTs is lightly addressed in the "Ley General de Salud" although there are no specific considerations about, for example, consumer protection or the number of embryo's that should be implanted.

${ }^{30}$ F. Luna. 2002. Assisted Reproductive Technology in Latin America: Some Ethical and Sociocultural Issues. Current Practices and Controversies in Assisted Reproduction 17-21 Sept 2001. Geneva: World Health Organisation. E. Vayena, P. Rowe and G. David, eds. 31-39. Available at: http://www.who.int/reproductive-health/infertility/7.pdf [Accessed 8 Oct 2008].

${ }^{31}$ SAMeR. op cit. note 15.

${ }^{32}$ REDLARA. op cit. note 16.

${ }^{33}$ Luna. op cit. note 30.

${ }^{34}$ Pennings. op cit. note 9.
} 


\section{Safety and market interests}

In a free market, a company's reputation will depend to a large extent on customer satisfaction, thus there is an incentive to produce or offer services and products that are safe and effective; ${ }^{35}$ in the case of fertility services, this would mean that clinics have an interest in offering quality services that also have a high probability of resulting in a successful pregnancy. Medical tourists likely have high expectations, often travelling great distances expecting a one-time treatment with a successful outcome. There may be little acceptance of failure and the ensuing need to repeat the travel and the procedure. ARTs are not simple procedures, nor are they guaranteed to produce a live birth. Fertility treatments do allow many couples to conceive and deliver healthy babies, but as has been shown by numerous clinical and epidemiological studies, rates of 'take home babies' (which vary substantially between clinics) average only 15 to $30 \%$; the chance of having a successful birth drops dramatically with each subsequent round of treatment.

It is in the interest of both clients and service providers to maximise the chance of a successful pregnancy in the absence of medical complications, so in many cases this leads to the implantation of multiple embryos. There is evidence that in private fertility clinics, higher numbers of embryos are transferred in a given ART procedure, particularly in countries where private heath care systems predominate, such as in the United States and most of the developing world, including Latin America. One study found that the number of embryos implanted by fertility clinics in developing countries was double ( 4 on average) that of clinics in countries with predominantly socialized medicine (e.g. in Northern Europe or Australia). ${ }^{36}$ In these latter countries, clinics tend to implant fewer embryos in order to avoid the occurrence of multiple pregnancies and associated health risks (e.g. complications associated with the birth of multiple low weight babies), and reduce associated costs to national health care systems. So while some consumer and clinic interests may converge (high pregnancy rates at lower cost), there may also be divergence regarding such factors as the risks and costs to consumers and home country health care systems (minimizing rates of multiple births and expensive follow-up care).

Final points for consideration are the role and associated accountability of foreign treating physicians, which may differ from those in the medical tourists' home countries. The staff at non-accredited clinics such as Plenitas and Go Sculptura very likely offer quality services; the doctors at these two clinics have medical degrees from reputable universities and are specialists affiliated with major research hospitals and clinics. Nonetheless, it is still important for potential customers to consider the role of the treating physicians in Argentina. Unlike their personal physician in their home country, with whom patients have a fiduciary relationship - the physician has a responsibility to look out for the patient's best interests - the foreign doctor is an employee of the private clinic that sells services in a relatively unregulated system. As such, the doctor is in a conflict of interest because of dual loyalties. ${ }^{37}$ As a doctor, his or her duty is to the patient (a duty based in professional codes of ethics), but as an employee of the clinic, the doctor is expected to sell the clinic's services and deliver them within a prescribed cost structure limited by fixed price considerations (as discussed previously). Further, in practice the doctor's responsibility ends when the patient leaves the clinic in Argentina; there are no mechanisms for follow-on or long-term supervision should such care be necessary. In short, the medical tourist

\footnotetext{
${ }^{35}$ H. Marcus, D. Marcus \& S. Marcus. How Do Infertile Couples Choose Their IVF Centers? An InternetBased Survey. Fertil Steril 2005; 83: 779-781

${ }^{36}$ F. Luna. 2006. Bioethics and Vulnerability; a Latin American View. Amsterdam: Rodopi

${ }^{37}$ J.P. Kassirer. Financial Conflict of Interest: An Unresolved Ethical Frontier. Am J Law Med 2001; 27: 149-162
} 
must be aware that the patient-physician relationship differs significantly from the commercial business-client arrangement or contract for services. ${ }^{38}$

\section{Implications for the key actors involved in reproductive tourism}

The preceding analysis highlighted a number of concerns raised by the growing reproductive tourism industry. As discussed earlier, there are good arguments for both opponents and proponents of the practice of reproductive tourism. We do not argue here that this practice should be prohibited; private fertility clinics offer services that many people are willing to pay for, but which may not be considered (e.g. by decision makers) sufficiently important to warrant provision as part of public health insurance plans. Rather, our intent is to clarify the key implications and responsibilities for the actors involved (i.e. consumers, health professionals, policy makers, and civil society), in order to substantiate our claim that more formal regulatory mechanisms are necessary to encourage greater transparency and accountability, ensure safe clinical practices, and protect public health and welfare.

\section{Health Care Consumers}

As previously mentioned, many consumers looking to travel to Argentina to access fertility services are provided information on clinic websites that trivialises or under-represents the important risks involved in such procedures, or that offers only partial and ultimately self-serving facts. The consumer is often ill informed about important details of such treatments, including the possibility and/or need for follow-up care, which may well lead to unwise decisions or choices. As has been discussed in some detail in the ethics and policy literatures dealing with access to private health care (whether or not in the context of medical tourism), the consumer is reasonably thought of as an autonomous agent and as such responsible for his or her decisions. ${ }^{39}$ Accordingly, consumers of fertility services should select clinics carefully and evaluate related information, particularly where there is appropriate regulation and oversight (and thus some measure of quality assurance). ${ }^{40}$ But it would be unfair and unrealistic to ascribe to patients, as consumers, full responsibility for evaluating the quality and conduct of highly specialised and technical health care procedures; such capacities go well beyond what can be expected of even the most educated members of the general public. It is thus also important to consider the interests, roles and responsibilities of the other actors involved in the provision of private fertility services, something which has received comparatively little attention in the literature.

\section{Health Professionals}

Health professionals - as members of formal professions (i.e. with monopoly powers, professional independence, and social prestige) entrusted with a patient's health - commonly have fiduciary relationships with their patients. While respect for patient autonomy, and thus decision making, is an important factor in most patient-physician relationships in North America and Europe, patients still seek medical professionals whom they can trust to provide advice that will be in the patient's best interests. As we have shown, health professionals in private clinics, whether or accredited or not, may be in important conflicts of interest because of their dual loyalties (to patients and to their employer); this situation is only exacerbated in the case of health professionals working in non-accredited clinics operating in the medical tourism sector. These health professionals might be influenced to recommend patients to undertake more risky

\footnotetext{
${ }^{38}$ G. Pennings, et al. ESHRE Task Force on Ethics and Law 15: Cross-Border Reproductive Care. Hum Reprod 2008; 23: 2182-2184

${ }^{39}$ S.H. Woolf, et al. Promoting Informed Choice: Transforming Health Care to Dispense Knowledge for Decision Making. Ann Intern Med 2005; 143: 293-300

${ }^{40}$ Marcus, Marcus \& Marcus. op cit. note 35.
} 
medical practices (e.g. implantation of multiple embryos); and where there is little information about clinical outcomes (because gestation and actual birth occurs abroad, in the medical tourist's home nation), and non-existent oversight and regulation, there may be few negative consequences associated with such risky medical practices.

Health professionals in private clinics in developed countries may arguably be less inclined to engage in practices that could be deemed unprofessional, due to stringent oversight mechanisms and the potential for costly and professionally embarrassing law suits. By extension, in a competitive and increasingly global market for fertility services, private clinics in developed countries (but also in developing countries) may have a strong incentive to provide high quality services to attract medical tourists. Simply because a private clinic is non-accredited does not mean that it provides lower quality services than accredited clinics; but it is important to pay attention to the diverse and sometimes conflicting interests that are at stake.

\section{Policy Makers}

Many nations, in both the developed and developing worlds, have encouraged the practice of medical tourism because it has the potential to contribute to significant economic development. ${ }^{41}$ But if the safety and quality of care do not meet internationally recognised standards, or are not up to par with those of competing nations, then a country's reputation as a medical tourism destination will eventually be compromised, thereby undermining market share and potential economic benefits. Thus alongside their obligation to protect public health, policy makers in countries such as Argentina that are developing medical tourism sectors also have an interest in implementing rigorous oversight mechanisms to ensure that the highest quality services are provided. Paradoxically, the case can be made that overly restrictive legislation controlling access to fertility services in developed countries actually encourages reproductive tourism. ${ }^{42}$

Nonetheless, basic safety standards and quality control are still an essential element in the effective provision of fertility services; the challenge will be in deciding which specific mechanisms are most appropriate in light of social, cultural and economic differences. Policy makers and national leaders must recognize that implementing regulatory mechanisms may take considerable time, and that to be effective they will have to also consider other potentially competing interests, i.e. those of health professionals and private clinics. Although it can be agued that many developing economies such as Argentina lack the capacity to promote responsive regulation through top-down government legislation, these countries are not without alternatives. Local and international NGOs or established local and regional systems may be important mechanisms with which to regulate the private market. ${ }^{43}$ For instance, by building on already established registries such as SAMeR and REDLARA, and making their standards obligatory instead of voluntary (as is currently the case), Argentinean policy makers could contribute to both the health and wealth objectives.

Developed countries such as a Canada, the United States or members states of the European Union already have well established oversight mechanisms to regulate public and private sector fertility clinics. But they also arguably have an interest in promoting the development of better regulations internationally. ${ }^{44}$ Since their citizens are increasingly opting to go abroad for

\footnotetext{
${ }^{41}$ Turner. op cit. note 19.

${ }^{42}$ G. Pennings. Legal Harmonization and Reproductive Tourism in Europe. Hum Reprod 2004; 19: 26892694

${ }_{43} \mathrm{~J}$. Braithwaite. Responsive Regulation and Developing Economies. World Dev 2006; 34: 884-898

${ }^{44}$ Pennings, et al. op cit. note 38.
} 
reproductive services, developed countries will bear the costs of providing potentially costly follow-up care to returning citizens should they suffer eventual complications from accessing risky, less-then-optimal procedures abroad. This is particularly true in the case of fertility treatments where complications will only manifest themselves at a latter stage of pregnancy, long after the individual has returned home.

\section{Civil Society}

Fertility clinics in Argentina are for the most part private entities, offering services only to those who can pay or who have sufficient private health insurance coverage. Given that ARTs are not covered by public health insurance plans in Argentina (and thus are of limited access), one might argue that there is no specific interest for Argentinean civil society with regards to how such services are regulated. However, there may well be a trickle down affect on the Argentinean economy if the various actors involved in service provision adopt or permit risky medical practices. As already mentioned, an unregulated reproductive tourism sector runs the risk of clinics losing their reputation for quality service provision, with the result that medical tourists opt to purchase services from clinics in other countries. This could then have a negative impact on access to services, (e.g. if clinics close) for those Argentineans who can afford to purchase ARTs, as well threatening the long term development of quality fertility service provision in the country.

\section{CONCLUSION}

As relatively new players in the medical tourism industry, private clinics in Argentina are now offering a diversity of medical services, including access to assisted reproductive technologies. A comparative website analysis revealed the existence of two subcategories of private fertility clinics: 1) accredited and affiliated clinics that are part of the broader health care industry; and 2) non-accredited clinics focused on medical tourism. Fertility clinics offer a wide variety of fertility services, often combined with other services and tourist features, for a fixed price. In this paper, we discussed a number of issues associated with medical tourism and related practices as evidenced in the practices of two non-accredited Argentinean fertility clinics, Plenitas and Go Sculptura.

Whether or not one thinks that reproductive services should be made available for private purchase, it is clear that consumers are purchasing such services. We argue that countries such as Argentina that currently lack formal oversight mechanisms should enact legislation to regulate the conduct of private fertility clinics in order to ensure that consumer information is accurate and that services provided are safe and effective. Some medical facilities that cater to medical tourists seem to be moving towards ensuring provision of more responsible practices, and for example, are sending their doctors to reside abroad (in developed countries) in order to provide follow-up care. ${ }^{45}$

Self-regulation of the fertility industry (by clinics and medical professionals) is an important step in the right direction, but is arguably still insufficient. It is our contention that both resident and medical tourist destination countries have a strong interest in promoting effective regulation of the fertility sector. Not only is it in the best interest of the patient, but it also makes good business sense for the resident country (e.g. in the developed world) to avoid costs resulting from health complications of its citizens, and for the foreign country providing medical tourism services to maintain client trust and ensure market share over time. Reproductive tourism is a

\footnotetext{
${ }^{45}$ R.C. Merrell, et al. Medical Tourism. Telemed J E Health 2008; 14: 14-20. Available at: http://www.liebertonline.com/doi/abs/10.1089/tmj.2008.9995 [Accessed 8 Oct 2008].
} 
growing phenomenon, one which has many socio-ethical implications for health care consumers, medical professionals, private clinics, and for policy makers. Without public, academic, and political reflection and action on the specific issues raised by reproductive tourism, the private provision of ARTs will continue to be under-regulated, lack minimal quality standards, and pose significant risks for both health care consumers and nations. 